\title{
A SYSTEMATIC REVIEW OF PHARMACOLOGICAL INTERVENTIONS TO ENHANCE SYSTEMIC CIRCULATION IN LATE PRETERM ( $\geq 32$ WEEKS GESTATION) AND TERM INFANTS WITH PPHN
}

\section{Olivia Stamm, Advanced Neonatal Nurse Practitioner - Princess Anne Hospital Southampton/UK \\ Dr. Mike Hall, Neonatal Consultant - Princess Anne Hospital Southampton/UK}

Background and aims: Neonates with persistent pulmonary hypertension of the newborn (PPHN) often suffer cardiac dysfunction and/or low systemic blood pressure (BP). A systematic review was performed to assess the evidence for pharmacological interventions which enhance the systemic circulation in late preterm and term infants with PPHN.

Method: EMBASE, Medline, CINAHL, Cochrane Library, Google Scholar, ScienceDirect and Web of Science were searched between November 2016 and September 2017; prospective registers and reference lists were also scanned. Quantitative studies were eligible for inclusion. The methodological quality of the studies was assessed using the Critical Review Form - Quantitative Studies from McMaster University. Primary outcomes were improvement of cardiac function and systemic hypotension. Secondary outcomes included adverse effects.

Results: Nine eligible studies were found; four investigated milrinone, three dopamine/noradrenaline/adrenaline and two vasopressin. Four were prospective and five retrospective; no RCT was found. Milrinone was reported to improve cardiac function but a transient drop in mean arterial BP was observed. Noradrenaline improved cardiac function and systemic BP. Vasopressin showed a significant improvement in systemic BP and left ventricular (LV) function. Study methodologies were too heterogeneous to allow meta-analysis.

\begin{tabular}{|c|c|c|c|c|}
\hline Author & Population & $\begin{array}{l}\text { Mean GA } \\
\text { (weeks) }\end{array}$ & Intervention & Significant improvements were reported in: \\
\hline $\begin{array}{l}\text { James et al. } \\
\quad(2016)\end{array}$ & 17 infants PPHN & 39.8 & Milrinone & $\begin{array}{r}\text { Reduction of systolic, diastolic and mean BP }(p=0.004) \text {, increase in RV basal } \\
\text { longitudinal strain }(p=0.01) \text {, systolic strain rate }(p=0.002) \text { and fractional area change } \\
(p=0.007), \text { in LV s' and a' waves, increase in myocardial performance index }(p=0.003) \\
\text { and LV output }(p=0.004)\end{array}$ \\
\hline $\begin{array}{l}\text { Patel et al. } \\
\text { (2012) }\end{array}$ & $\begin{array}{c}6 \text { infants with } \mathrm{CDH} \text { and } \\
\text { severe PPHN }\end{array}$ & 38.6 & Milrinone & Progressive increase in early diastolic (E') velocities in the $R V(p=<0.05)$ \\
\hline $\begin{array}{l}\text { McNamara et al. } \\
\text { (2006) }\end{array}$ & $\begin{array}{l}9 \text { full term infants with severe } \\
\text { PPHN }\end{array}$ & 39.2 & Milrinone & Improvement in heart rate $(p<0.001)$ \\
\hline $\begin{array}{l}\text { McNamara et al. } \\
\text { (2013) }\end{array}$ & 11 neonates with PPHN & 39.2 & Milrinone & $\begin{array}{l}\text { Ratio of RV ejection time to pulmonary artery acceleration time }(p<0.05) \text {, increased RV } \\
\text { output }(p<0.05) \text { and LV output }(p<0.05) \text {, lower proportion of right-left transductal } \\
\text { shunting }(p<0.05)\end{array}$ \\
\hline $\begin{array}{l}\text { Buijs et al. } \\
(2014)\end{array}$ & $\begin{array}{l}28 \text { patients with } \mathrm{CDH} \text { of whom } \\
20 \text { with PPHN }\end{array}$ & $\begin{array}{l}38.3- \\
39.4\end{array}$ & $\begin{array}{l}\text { Dopamine } \\
\text { Norepinephrine } \\
\text { Epinephrine }\end{array}$ & $\begin{array}{l}\text { Increase in heart rate after starting norepinephrine }(p=0.023) \text {, increase in mean arterial } \\
\text { BP after starting dopamine }(p=0.001) \text { and norepinephrine/epinephrine }(p=0.046)\end{array}$ \\
\hline $\begin{array}{c}\text { Tourneux et al. } \\
(2008)\end{array}$ & 22 term infants, 15 with PPHN & 39.1 & Noradrenaline & Increase in systemic BP by $40 \%(p<0.001)$, increase in heart rate $(p<0.05)$ \\
\hline $\begin{array}{l}\text { Tourneux et al. } \\
\text { (2008) }\end{array}$ & 18 newborns with PPHN & 37 & Norepinephrine & $\begin{array}{r}\text { Increase in mean systemic artery pressure }(p<0.05) \text {, systolic and diastolic SAP } \\
(p<0.001), \text { LV output increased by } 22 \%(p<0.05) \text {, increased end diastolic LV diameter } \\
(p<0.05) \text {, mean PAP/SAP ratio decreased }(p<0.001) \text {, ductus arteriosus shunting } \\
\text { switched from bidirectional to exclusive left-right in } 8 \text { infants }\end{array}$ \\
\hline $\begin{array}{l}\text { Mohamed et al. } \\
\text { (2014) }\end{array}$ & $\begin{array}{l}10 \text { term infants with severe } \\
\text { PPHN }\end{array}$ & 38.8 & Vasopressin & Improvement in systolic, diastolic and mean BP $(p<0.001)$ \\
\hline $\begin{array}{l}\text { Acker et al. } \\
(2014)\end{array}$ & $\begin{array}{l}13 \text { infants with PPHN } \\
6 \text { infants did not require } \\
\text { ECMO }\end{array}$ & $36-41$ & Vasopressin & $\begin{array}{l}\text { All results only relate to the } 6 \text { patients not requiring ECMO: drop in heart rate, in } 4 \text { out } \\
\text { of } 7 \text { infants, LV function improved and ECMO was no longer indicated. }\end{array}$ \\
\hline
\end{tabular}
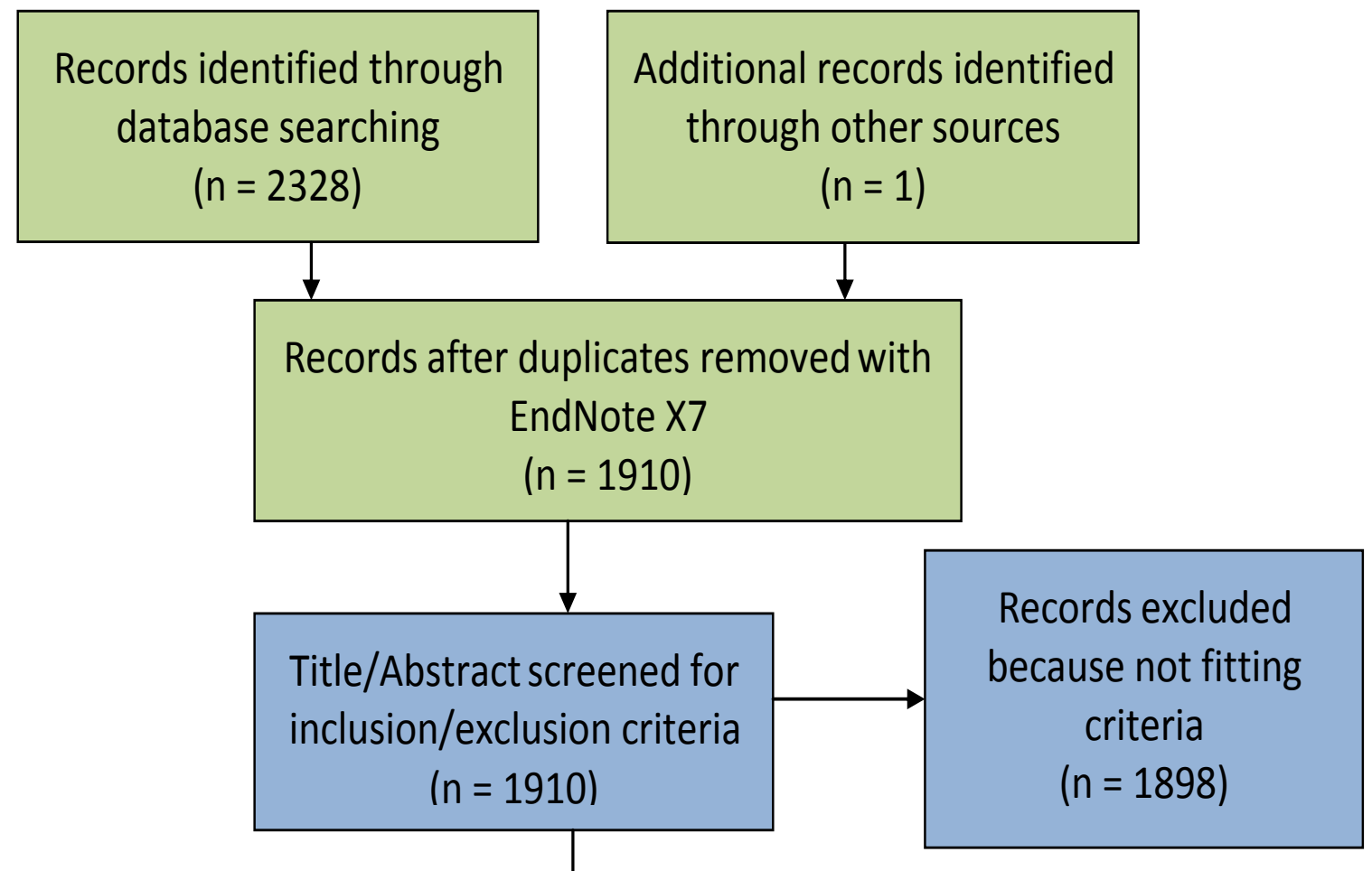

Full-text articles excluded with reasons $(n=3)$

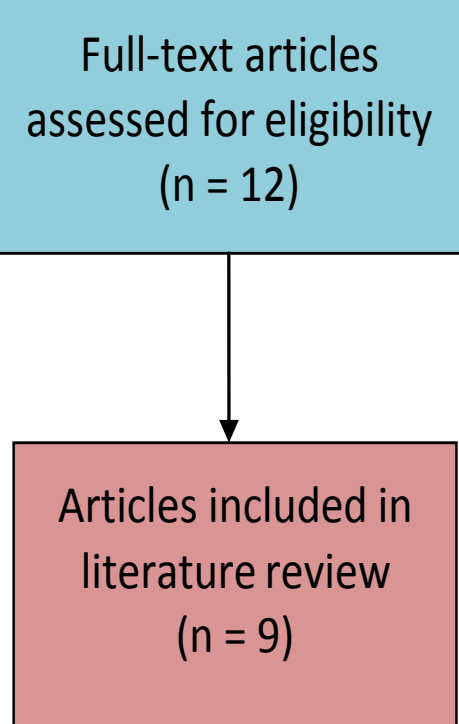

Study flow chart to identify and select eligible studies

Conclusion: All nine studies were low in the evidence hierarchy. They provide some evidence that milrinone, noradrenaline and vasopressin improve cardiac function and/or systemic hypotension, although all showed some adverse effects.

= only 4 cases which are not compared with each other including one infant of 26 weeks of gestation

$2=$ population not fitting nclusion criteria 